\title{
Mercaptoethanol-resistant human serum antibodies reacting with endotoxin from Neisseria gonorrhoeae ${ }^{\star}$
}

\author{
JOHAN A. MELAND AND BODIL LARSEN† \\ Department of Dermatology and Broegelmann Research Laboratory for Microbiology, School of Medicine, \\ University of Bergen, 5000 Bergen, Norway
}

The rising incidence of gonorrhoea has stimulated research on the elaboration of reliable serological tests for its diagnosis. We have reported results obtained in indirect haemagglutination tests for detection of antibodies to the carbohydrate determinant $a$ and the protein determinant $b$ of endotoxin from strains of gonococci (Mæland and Larsen, 1971). It was found that most human sera contained antibodies against both antigens and that the titres of sera from patients with gonorrhoea were comparable to those of sera from blood donors. After treatment of serum with mercaptoethanol, the control sera showed no antibody activity in tests with serum diluted 1 in 8 . However, at this dilution, sera from approximately one-third of the patients studied demonstrated activity in the haemagglutination test.

We have pursued the question whether the haemagglutination test can be of value in the diagnosis of gonorrhoea when mercaptoethanol-treated serum is used instead of untreated serum. This report presents the results obtained by testing sera for antibodies against determinant $b$ from one strain of gonococcus and determinant $a$ from three different strains after treatment of the sera with mercaptoethanol.

\section{Material and methods}

SERA

Sera from fifty patients with gonorrhoea (eighteen females and 32 males), from thirty males with non-specific urethritis, and from eighty blood donors were examined. All patients were treated at the Outpatients Clinic for Venereal Diseases, the University Hospital, Bergen. The diagnosis of gonorrhoea was verified bacteriologically. Patients with non-specific urethritis had no history of previous venereal disease and gonorrhoea was excluded.

Antisera to human IgA (Tönder and Larsen, 1970), IgG, and $\operatorname{IgM}$ (Larsen and Tönder, 1969) were raised in

Received for publication June 10, 1974

*This investigaton was supported in part by the Norwegian Research Council for Science and the Humanities

†Present address: Memorial University of Newfoundland, School of Medicine, St. John's, Newfoundland, Canada rabbits. Immunoelectrophoresis of human serum was used to test for monospecificity of the antisera. The precipitation titre of the antiglobulins was determined by gel diffusion as described by Beutner, Sepulveda, and Barnett (1968), and the sera were diluted to contain $0.25 \mathrm{U} / \mathrm{ml}$. antibody before use in the antiglobulin test.

Antisera to gonococci, Strains 8551, V, and VII, were prepared by immunization of rabbits as previously reported (Mæland, 1966). The sera were made specific for each of the antigens $a-8551, a-\mathrm{V}, a-\mathrm{VII}$, and $b-\mathrm{V}$ (see below) by appropriate absorption as follows: antiserum containing antibodies to $b-\mathrm{V}$ but not to $a-\mathrm{V}$ was prepared by absorption of antiserum to Strain $\mathrm{V}$ with pronasedigested lipopolysaccharide from this strain (Mæland, 1968). Antiserum specific for each of the $a$-determinants was prepared by absorption of serum with lipopolysaccharides containing the other $a$-determinants. The lipopolysaccharides to be used for absorption were chosen according to their factor formulae and the technique was as described by Mæland, Kristoffersen, and Hofstad (1971).

All sera were heated at $56^{\circ} \mathrm{C}$. for $30 \mathrm{~min}$. to inactivate complement.

\section{TREATMENT OF SERA}

Reduction of serum by 2-mercaptoethanol (ME) was performed by mixing equal volumes of $0.2 \mathrm{M} \mathrm{ME}$ and serum diluted 1 in 2 . The mixture was incubated at $37^{\circ} \mathrm{C}$. for $30 \mathrm{~min}$. and then absorbed with sheep erythrocytes to remove heterophil antibodies. Serum was tested for serological activity without further treatment. Sera to be digested with pepsin were treated with $M E$, dialysed against $0.11 \mathrm{M}$ iodacetamide (Fluka, AG) at $4^{\circ} \mathrm{C}$. for $20 \mathrm{hrs}$, and finally against phosphate-buffered saline pH $7 \cdot 2$. The gammaglobulins were then collected by precipitation with $1.33 \mathrm{M}\left(\mathrm{NH}_{4}\right)_{2} \mathrm{SO}_{4}$ and digested with pepsin $(2 \times$ crystallized, Sigma Chemical Company, St. Louis, Mo.) as reported by Natvig (1966).

\section{ANTIGENS}

Lipopolysaccharides were prepared from gonococci of Strains 8551, V, and VII. The phenol-water extraction and purification procedures have been described (Mrland, 1968). The $a$-determinants ( $a-8551, a-\mathrm{V}$, and $a$-VII) were obtained by treatment of the various lipopolysaccharides with $\mathrm{NaOH}$ and digestion with pronase (Mæland, 1969a). 
Aqueous ether endotoxin was prepared from Strain V (Mxland, 1968). The preparation was further processed by treatment with $\mathrm{NaOH}$ and oxidation with periodate to obtain determinant $b(b-\mathrm{V})$ (Mæland, 1969a). The final preparations were stored frozen.

\section{SENSITIZATION OF ERYTHROCYTES}

Sheep erythrocytes were washed, packed, and sensitized with the various antigens as reported by Mæland and Larsen (1971). The sensitizing activity of the antigen was measured in a checker-board titration, using selected sera from patients with gonorrhoea. In the final tests, from 0.125 to $0.5 \mathrm{mg}$. of the various antigens were used for the sensitization of $1 \mathrm{ml}$. of 1 per cent. suspension of erythrocytes. These amounts corresponded to 8 to 16 times the least amount of antigen giving sensitization for maximal titre with the selected sera.

\section{INDIRECT HAEMAGGLUTINATION (HA) TEST}

For screening of sera $0.1 \mathrm{ml}$. of sensitized erythrocytes ( 0.5 per cent. suspension) was added to $0.4 \mathrm{ml}$. of MEtreated serum. The controls, incubation, and reading of the agglutination were as reported earlier (Mæland and Larsen, 1971). All sera which showed agglutination were then examined after two-fold dilutions for determination of titres, i.e. the reciprocal of the highest serum dilution showing definite agglutination.

\section{ANTIGLOBULIN TEST}

The antiglobulin test with ME-treated serum was performed and the results recorded as reported earlier (Mæland and Larsen, 1971).

\section{Results}

\section{$H A$ test with $M E$-treated sera}

All human sera were examined by the HA test after treatment with ME. In order to confirm that treatment with ME destroyed the reactivity of IgM antibodies, sera from patients with infectious mononucleosis were treated similarly. The activity of agglutinins to sheep erythrocytes was lost after this treatment.
In each of the three groups studied, the number of sera with activity in the HA test varied according to the antigen used (Table I). Tests with erythrocytes sensitized with $a$-VII gave the highest numbers of reactive sera in both patients and controls. In sera from patients with gonorrhoea, antibody to the various $a$ determinants was found more frequently than antibody to the $b$ determinant.

The percentage of reactive sera in tests with the various antigens ranged from 17 to 32 per cent. for blood donors, 13 to 20 per cent. for patients with non-specific urethritis, and 64 to 82 per cent. for patients with gonorrhoea. Activity in the HA test was thus found more frequently in sera from patients with gonorrhoea than in either of the control groups.

The titres obtained ranged from 1 to 256 in patients with gonorrhoea and from 1 to 16 in the controls except for one control serum (Table I). However, the majority of sera from patients had titres $<16$, those with titres higher than 16 ranging from 12 to 18 per cent., depending on the antigen used. The means of titres (in $\log 2$ units) were calculated and were found to be nearly the same for each of the various groups of sera in tests with various antigens. Thus the mean values for patients with gonorrhoea were $1.86(a-8551), 1.84(a-\mathrm{V}), 1.90(a-\mathrm{VII})$, and 1.54 $(b-\mathrm{V})$ respectively. Comparison by $t$-test showed that the mean titres of patients' sera were significantly higher than those of the controls with all four antigens $(P<0.01)$. Female patients had higher mean titres than males irrespective of the antigen used, the distinction being statistically significant only with $a-8551(\mathrm{P}<0.05)$.

Many sera had titres which varied according to the antigen used, as shown by the examples listed in Table II. Consequently, the number of antigens used for the testing of each serum would affect the total number of sera with titres higher than some defined value. Thus 32 per cent. of sera from patients with gonorrhoea had titres $>16$ with one

TABLE I Serum from blood donors (B.d.), patients with non-specific urethritis (U.pat.), or gonorrhoea (Gc.pat.) examined by the indirect $H A$ test for mercaptoethanol-resistant antibodies to determinant a of Strains 8551, V, and VII, and to determinant b

\begin{tabular}{|c|c|c|c|c|c|c|c|c|c|c|c|c|}
\hline $\begin{array}{l}\text { Serum } \\
\text { from }\end{array}$ & Antigen & $\underset{<1}{N u n}$ & of se & 2 & 4 & 8 & 16 & 32 & 64 & 128 & 256 & $\begin{array}{l}\text { No of sera } \\
\text { reactive/tested }\end{array}$ \\
\hline $\begin{array}{l}\text { B.d. } \\
\text { U.pat. } \\
\text { Gc.pat. }\end{array}$ & $a-8551$ & $\begin{array}{l}60 \\
26 \\
11\end{array}$ & $\begin{array}{r}6 \\
2 \\
11\end{array}$ & $\begin{array}{l}7 \\
1 \\
7\end{array}$ & $\begin{array}{l}1 \\
3\end{array}$ & $\begin{array}{l}4 \\
5\end{array}$ & $\begin{array}{l}3 \\
6\end{array}$ & 4 & 1 & 1 & 1 & $\begin{array}{r}20 / 80 \\
4 / 30 \\
39 / 50\end{array}$ \\
\hline $\begin{array}{l}\text { B.d. } \\
\text { U.pat. } \\
\text { Gc.pat. }\end{array}$ & $a-V$ & $\begin{array}{l}66 \\
26 \\
13\end{array}$ & $\begin{array}{r}4 \\
12\end{array}$ & $\begin{array}{l}4 \\
1 \\
4\end{array}$ & $\begin{array}{l}1 \\
1 \\
4\end{array}$ & $\begin{array}{l}4 \\
1 \\
3\end{array}$ & $\begin{array}{l}1 \\
1 \\
5\end{array}$ & 4 & 4 & 1 & & $\begin{array}{r}14 / 80 \\
4 / 30 \\
37 / 50\end{array}$ \\
\hline $\begin{array}{l}\text { B.d. } \\
\text { U.pat. } \\
\text { Gc.pat. }\end{array}$ & $a-V I I$ & $\begin{array}{r}54 \\
24 \\
9\end{array}$ & $\begin{array}{r}6 \\
2 \\
10\end{array}$ & $\begin{array}{r}13 \\
3 \\
13\end{array}$ & $\begin{array}{l}2 \\
2\end{array}$ & $\begin{array}{l}4 \\
1 \\
3\end{array}$ & $\begin{array}{l}1 \\
4\end{array}$ & 4 & 3 & 1 & 1 & $\begin{array}{r}26 / 80 \\
6 / 30 \\
41 / 50\end{array}$ \\
\hline $\begin{array}{l}\text { B.d. } \\
\text { U.pat. } \\
\text { Gc.pat. }\end{array}$ & $b-V$ & $\begin{array}{l}59 \\
27 \\
18\end{array}$ & $\begin{array}{l}4 \\
6\end{array}$ & $\begin{array}{l}7 \\
8\end{array}$ & $\begin{array}{l}4 \\
5\end{array}$ & $\begin{array}{l}1 \\
2 \\
5\end{array}$ & $\begin{array}{l}4 \\
2\end{array}$ & $\begin{array}{l}1 \\
3\end{array}$ & 1 & 3 & & $\begin{array}{r}21 / 80 \\
3 / 30 \\
32 / 50\end{array}$ \\
\hline
\end{tabular}


TABLE II Mercaptoethanol-resistant antibodies to determinant a of Strains 8551, V and VII and to determinant $\mathrm{b}$. Titres in the indirect $H A$ test of selected sera from patients with gonorrhoea

\begin{tabular}{|c|c|c|c|c|}
\hline \multirow[t]{2}{*}{ Serum no. } & \multicolumn{4}{|c|}{ Antigen } \\
\hline & a-8551 & a- $V$ & a-VII & b- $V$ \\
\hline $\begin{array}{l}1 \\
2 \\
3 \\
4 \\
5 \\
6 \\
7\end{array}$ & $\begin{array}{r}64 \\
32 \\
2 \\
2 \\
<1 \\
256 \\
4\end{array}$ & $\begin{array}{r}64 \\
<1 \\
<1 \\
128 \\
<1 \\
64 \\
4\end{array}$ & $\begin{array}{r}64 \\
<1 \\
16 \\
8 \\
2 \\
256 \\
4\end{array}$ & $\begin{array}{r}<1 \\
32 \\
32 \\
<1 \\
128 \\
128 \\
4\end{array}$ \\
\hline
\end{tabular}

or more of the antigens used, i.e. approximately twice the percentage obtained in tests with each of the antigens.

\section{Sensitization of erythrocytes with mixed solutions of endotoxin}

Experiments were performed to examine whether the procedure of testing serum for antibodies against several antigens could be simplified. Sensitization of erythrocytes was carried out using a mixture of the three $a$ determinants or all four antigens. The concentration of each antigen in the mixtures was the same as when sensitization was carried out with each of them singly. The treated erythrocytes were then examined for agglutination by rabbit antiserum made specific for each antigen. Table III shows that, in tests using erythrocytes sensitized with any one of the antigen mixtures, the titres of antibody to the various $a$ determinants was the same as that obtained in tests with erythrocytes sensitized with the corresponding antigen only. However, in tests with erythrocytes sensitized with a mixture of all four antigens, the titre of antibody to the $b$ determinant was reduced. The results show that erythrocytes exposed to any of the antigen mixtures became the carriers of the various antigens present. However, it appears that, when mixed with the $a$ determinants, sensitization with the $b$ determinant was achieved with reduced efficiency. Similar experiments using human serum await future investigation.

TABLE III Titres in indirect $H A$ test of rabbit antisera to Strains 8551, V, and VII after absorption of sera for cross-reacting antibodies

\begin{tabular}{|c|c|c|c|c|}
\hline \multirow{2}{*}{$\begin{array}{l}\text { Erythrocytes } \\
\text { sensitized } \\
\text { with }\end{array}$} & \multicolumn{4}{|c|}{ Serum specific for } \\
\hline & $a-8551$ & $a-V$ & $\mathrm{a}-V I I$ & b- $V$ \\
\hline $\begin{array}{l}a-8551 \\
a-V \\
a-V I I \\
b-V\end{array}$ & $\begin{array}{r}1,024 \\
<16 \\
<16 \\
<16\end{array}$ & $\begin{array}{l}<16 \\
256 \\
<16 \\
<16\end{array}$ & $\begin{array}{r}<16 \\
<16 \\
64 \\
<16\end{array}$ & $\begin{array}{l}<16 \\
<16 \\
<16 \\
1,024\end{array}$ \\
\hline $\begin{array}{l}a-8551, a-\mathrm{V} \\
a-\mathrm{VII}\end{array}$ & 512 & 256 & 64 & $<16$ \\
\hline $\begin{array}{l}a-8551, a-V \\
a-V I I, b-V\end{array}$ & 1,024 & 256 & 64 & 64 \\
\hline
\end{tabular}

Antiglobulin test with $M E$-treated serum and effect of digestion of immunoglobulins with pepsin

Ten ME-treated patients sera were examined in the antiglobulin test using anti-human IgG, IgA, and IgM, and erythrocytes sensitized with $a-\mathrm{V}$. All sera examined were active in the HA test. With anti-IgG the sera had titres in the antiglobulin test from 8 to 32 times higher than those obtained in the HA test. With anti-IgA or anti-IgM the titres were not augmented. The results indicate that the titre of the ME-treated sera in the HA test was determined by IgG antibodies.

Immunoglobulins isolated from the sera of five patients were examined by the HA test against $a-\mathrm{V}$ before and after digestion with pepsin. The preparations agglutinated the sensitized erythrocytes both before and after the digestion, indicating that the agglutination was mediated by the Fab portion of the immunoglobulins.

\section{Discussion}

Human sera were examined for ME-resistant antibodies to determinant $b$ of endotoxin from gonococci Strain V and determinant $a$ from Strains 8551, V, and VII. From investigations reported earlier, it would appear that treatment of human serum with ME eliminates the activity in the HA test of the 'normal' antibodies active against the endotoxin (Mæland and Larsen, 1971). However, in this study, from 17 to 32 per cent. of sera from blood donors were active in the HA test after treatment of serum with ME. The percentage depends upon the antigen used. It seems improbable that this frequency of reactive sera can be explained on the basis of infection with gonococci. Accordingly, MEresistant serum antibodies are not restricted to patients with gonorrhoea. On the other hand, we reported earlier that 66 per cent. of untreated sera from blood donors had titres $>8$ in the HA test with antigen from strain V (Mæland and Larsen, 1971). It therefore appears that the percentage of sera with activity due to normal antibodies is substantially reduced by treating the sera with ME.

The number of reactive sera was lower in patients with non-specific urethritis than in blood donors. One explanation could be that none of these patients had experienced gonorrhoea in the past, whereas some of the blood donors may have done so. Moreover, the patients were men below 30 years of age, whereas the blood donors included both sexes and covered a wider age range. This may have resulted in a higher frequency of normal antibodies in the blood donor group.

Of the sera from patients with gonorrhoea, 64 to 84 per cent. were active in the HA test as compared to 17 to 32 per cent. of the control sera. Furthermore, the mean titres were significantly higher than those 
of the controls with all four antigens. Female patients had higher titres of antibody than males. This is in accordance with the results reported by others (Danielsson, Thyresson, Falk, and Barr, 1972; Ward and Glynn, 1972). Whether this was due to longer duration of infection in females, higher frequency of recurrent infections, or complications of gonorrhoea, is not known. In the anti-globulin test, anti-human IgG but not anti-IgA or anti-IgM gave titres which exceeded by far those obtained in the HA test. This finding indicates that the titre of ME-treated serum in the HA test was determined by IgG antibodies against the sensitizing antigen and thus corroborates earlier findings (Mæland and Larsen, 1971). That the agglutination was mediated by the Fab portion of antibodies was shown by the activity of immunoglobulins digested with pepsin. It is tempting to conclude that patients with gonorrhoea are stimulated to produce IgG antibodies against endotoxin of the gonococcus. This is in agreement with reports by other investigators that patients with gonorrhoea produce humoral antibodies in response to the infecting organism (Cohen, Kellogg, and Norins, 1969; Fletcher, Miller, and Nicol, 1973; Danielsson and others, 1972; Wallace, Diena, Yugi, and Greenberg, 1970; Ward and Glynn, 1972). On the other hand, Watt, Ward, and Glynn (1971) have reported results which differ from those of the present study. They failed to detect ME-resistant human serum antibodies against the lipopolysaccharide from gonococci in a latex particle agglutination test. Furthermore, Cohen (1967) and Cohen and others (1969), using the indirect immunofluorescent technique, were unable to demonstrate an increased titre of $\mathrm{IgG}$ antibodies against heat-stable gonococcal antigens in patients with gonorrhoea. Their results also disagree with those of the present study, since it has been shown that the heat-stable antigens of gonococci include determinants $a$ and $b$ (Mæland, 1968).

In each group of individuals studied, the number of reactive sera and the average titre were nearly the same with all four antigens. Accordingly, none of the antigens used proved definitely superior to the others in tests for humoral antibodies. Many sera, however, had titres which varied according to the strain of gonococcus from which the antigen was prepared. This is similar to rabbit antisera against Strains 8551, V, and VII when tested against the $a$ determinants from the same strains (Mæland, 1969b; Mæland and others, 1971). It was found that the variation in titre of rabbit antisera was due to antibodies against several antigenic factors variously distributed among the three $a$ determinants. The variation in titre of human serum with different $a$ determinants could also be explained by assuming that antibodies of various specificities are involved. This interpretation is in agreement with results reported by others (Glynn and Ward, 1970; Watt and others, 1971) indicating strain-specificity of human antibodies to gonococcal antigens. For this reason, Glynn and Ward (1970) have recommended that several strains of gonococci should be used in diagnostic tests. This is supported by the present observation that 32 per cent. of patients with gonorrhoea had titres of ME-resistant antibodies higher than 16 with one or more of the antigens used compared to 12 to 18 per cent. with each of them. That the procedure of testing serum for antibodies against several antigens can be simplified was indicated by the finding that erythrocytes exposed to mixtures of endotoxin from different strains of gonococci became the carriers of the various endotoxins present. In addition, Fletcher and others (1973) have described a test for the detection of antibodies using erythrocytes sensitized with lipopolysaccharide from ten different isolates of gonococci.

\section{Summary}

Sera from fifty patients with gonorrhoea, thirty with non-specific urethritis, and eighty blood donors were treated with mercaptoethanol (ME) and examined by the indirect haemagglutination test for antibodies against endotoxin from gonococci. Erythrocytes sensitized with determinant $a$ of endotoxin from Strains 8551, V, and VII, or determinant $b$ from Strain V were used. The percentage of sera active in the haemagglutination test was much higher in the gonorrhoea group than in the controls. The geometric mean titre was also significantly higher in the gonorrhoea group. This applied for all four antigens used. Results obtained in an anti-globulin test indicated that the titre of ME-treated serum was determined by IgG antibodies against the endotoxin. Many sera had titres which varied according to the strain origin of the antigen used in the test. The sensitivity of tests for antibodies was increased by using endotoxin from several different strains of gonococci for the examination of each serum. A simplified procedure for determination of antibodies against endotoxin from different strains of gonococci was elaborated.

\section{References}

Beutner, E. H., Sepulveda, M. R., and Barnett, E. V. (1968) Bull. Wld Hlth Org., 39, 587

CoHeN, I. R. (1967) f. Bact., 94, 141

-, KellogG, D. S., and Norins, L. C. (1969) Brit. F. vener. Dis., 45, 325

Danielsson. D., Thyresson, N., Falk, V., and BarR, J. (1972) Acta derm.-venereol. (Stockh.), 52, 467

Fletcher, S., Miller, R., and Nicol, C. S. (1973) Brit. f. vener. Dis., 49, 508

GLYNN, A. A., and WARD, M. E. (1970) Infect. and Immun., 2, 16 
LARSEN, B., and TÖNDER, O. (1969) Vox Sang., 16, 69

MKLAND, J. A. (1966) Acta path. microbiol. scand., 67, 102 (1968) Ibid., 73, 413

(1969a) Ibid., 77, 495

(1969b) Ibid., 77, 505

, KRISTOFFERSEN, T., and Hofstad, T. (1971) Ibid., 79B, 233

and LARSEN, B. (1971) Brit. F. vener. Dis., 47, 269

Natvig, J. B. (1966) Acta path. microbiol. scand., 66, 369

Tönder, O., and LaRsen, B. (1970) Vox Sang., 18, 475

Wallace, R., Diena, B. B., Yugi, H., and GREENBERG, L. (1970) Canad. F. Microbiol., 16, 655

WARD, M. E., and GlYNN, A. A. (1972) f. clin. Path., 25, 56

WatT, P. J., WARD, M. E., and GlynN, A. A. (1971) Brit. F. vener. Dis., 47, 448

Anticorps sériques humains résistants au mercaptoéthanol et réagissant avec l'endotoxine obtenue à partir de Neisseria gonorrhoeae

SOMMAIRE

Les sérums de 50 gonococciques, de 30 malades atteints d'urétrite non spécifique et de 80 donneurs de sang, furent traités par le mercaptoethanol (ME) et examinés par l'épreuve de l'hémaglutination indirecte pour la recherche d'anticorps contre l'endotoxine provenant de gonocoques. On utilisa des hématies sensibilisées avec le déterminant $a$ de l'endotoxine provenant de souches 8551, V et VII ou avec le déterminant $b$ provenant de la souche V. Le pourcentage des sérums positifs dans le test d'hémaglutination fut nettement plus élevé dans le groupe gonococcique que chez les témoins. Le titre de la moyenne géométrique fut également significativement plus élevé dans le groupe gonococcique. Ceci valut pour l'ensemble des quatre antigènes utilisés. Les résultats obtenus dans un test antiglobulinique indiqua que le titre des sérums soumis au ME était dépendants des anticorps IgG contre l'endotoxine. De nombreux sérums avaient des titres variant selon la souche dont provenait l'antigène utilisé dans l'épreuve. La sensibilité des tests pour les anticorps lors de l'examen de chaque sérum fut accrue par l'emploi d'une endotoxine provenant de plusieurs souches différentes de gonocoques. On élabora un procédé simplifié pour la détermination des anticorps contre l'endotoxine provenant de différentes souches de gonocoques. 